\title{
HISTORICALAND ARCHITECTURAL HERITAGE OF VOLGOGRAD: ICONIC OBJECTS OF THE SQUARE OF FALLEN FIGHTERS OF PRE-WAR AND WAR STALINGRAD ${ }^{1}$
}

\author{
Irina N. Litvinova \\ Volgograd State University, Volgograd, Russian Federation \\ Oksana A. Karagodina \\ Volgograd State University, Volgograd, Russian Federation
}

\begin{abstract}
Introduction. The article analyzes the history of the creation of architectural objects surrounding the main square of the city - the Square of Fallen Fighters in the pre-war period of 1928-1938. The sequence of development of the square with new buildings of the era of "industrial constructivism", as well as the reconstruction of houses built in Tsaritsyn, is covered in detail. Methods and materials. The study is based on the objectivity principles and applies general scientific as well as specific historical methods. The authors pay attention to the facts related to solving the problems of transforming pre-war Stalingrad into a "socialist city" - the center of industry and culture in the Lower Volga region. Separate events of the first period of the assault on Stalingrad related to the defense of iconic buildings in the central part of the city, which turned into nodes of resistance of the Soviet troops in the September street battles, are considered. Buildings and structures of the pre-war period of the city's life that represented the appearance of the urban environment of Stalingrad, including the Square of Fallen Fighters, were forever lost to posterity. The purpose of the work is to analyze the historical architectural features of the main square and the surrounding area for subsequent computer modeling of the lost historical and cultural objects of pre-war Stalingrad based on the methodology of 3D reconstruction of structures. This approach to the historical heritage, which the city lost during the years of harsh atheistic propaganda and war, is partly able to recreate for contemporaries and subsequent generations various stages of life in Volgograd, with a characteristic appearance and features that reflect the characteristics of the city's environment. Historical and analytical material is necessary for compositional modeling, which will allow reconstructing architectural objects of pre-war Stalingrad for further research and use in the development of a virtual tour.
\end{abstract}

Key words: Square of Fallen Fighters, pre-war Stalingrad, "socialist city", architecture, buildings, street fighting.

Citation. Litvinova I.N., Karagodina O.A. Historical and Architectural Heritage of Volgograd: Iconic Objects of the Square of Fallen Fighters of Pre-War and War Stalingrad. Vestnik Volgogradskogo gosudarstvennogo universiteta. Seriya 4. Istoriya. Regionovedenie. Mezhdunarodnye otnosheniya [Science Journal of Volgograd State University. History. Area Studies. International Relations], 2021, vol. 26, no. 1, pp. 238-252. (in Russian). DOI: کิ https://doi.org/10.15688/jvolsu4.2021.1.21

\section{ИСТОРИКО-АРХИТЕКТУРНОЕ НАСЛЕДИЕ Г. ВОЛГОГРАДА: ЗНАКОВЫЕ ОБЪЕКТЫ ПЛОЩАДИ ПАВШИХ БОРЦОВ ДОВОЕННОГО И ВОЕННОГО СТАЛИНГРАДА ${ }^{1}$}

\author{
Ирина Николаевна Литвинова
}

Волгоградский государственный университет, г. Волгоград, Российская Федерация 


\title{
Оксана Александровна Карагодина
}

\author{
Волгоградский государственный университет, г. Волгоград, Российская Федерация
}

Аннотация. В статье анализируется история создания архитектурных объектов, окружавших главную площадь города - Павших Борцов в довоенный период (1928-1938 гг.). Подробно освещена последовательность застройки Площади новыми зданиями эпохи «индустриального конструктивизма», а также реконструкция домов царицынской постройки. Авторы уделяют внимание фактам, связанным с решением задач по превращению довоенного Сталинграда в «социалистический город» - центр индустрии и культуры в Нижнем Поволжье. Рассматриваются отдельные события первого периода штурма Сталинграда, связанные с обороной знаковых зданий центральной части города, превратившихся в узлы сопротивления советских войск в сентябрьских уличных боях. Здания и сооружения довоенного периода жизни города, представлявшие облик городской среды Сталинграда, включая площадь Павших Борцов, были навсегда утрачены для потомков. Цель работы - необходимость исторического анализа архитектурных объектов главной Площади и ближней территории для последующего компьютерного моделирования утраченных историко-культурных объектов довоенного Сталинграда на основе методологии 3D-реконструкции сооружений. Данный подход к историческому наследию, которого город лишился в годы жесткой атеистической пропаганды и войны, отчасти способен воссоздать для современников и последующих поколений различные этапы жизни Волгограда с характерными для них обликом и чертами, которые отражают особенности окружающей среды города. Историко-аналитический материал необходим для композиционного моделирования, что позволит реконструировать архитектурные объекты довоенного Сталинграда для их дальнейшего анализа и использования в разработке виртуальной экскурсии. Авторы И.Н. Литвинова и О.А. Карагодина занимаются исследованиями в сфере социальной истории Царицына и Сталинграда, городской среды, историко-культурными особенностями досоветского и довоенного периодов развития Волгограда. В данной статье И.Н. Литвинова анализировала процесс становления Сталинграда как «социалистического города», то есть успешного индустриального и культурного центра Нижневолжского края; занималась визуальной реконструкцией историко-архитектурных объектов площади Павших Борцов. Автор О.А. Карагодина исследовала историю строительства Сталинградского универмага на главной Площади, а также оборонительные бои советских войск в сентябре 1942 г. за знаковые здания центральной части города и сохранившиеся после боев архитектурные объекты площади Павших Борцов.

Ключевые слова: площадь Павших Борцов, довоенный Сталинград, «социалистический город», архитектура, здания, уличные бои.

Цитирование. Литвинова И. Н., Карагодина О. А. Историко-архитектурное наследие г. Волгограда: знаковые объекты площади Павших Борцов довоенного и военного Сталинграда // Вестник Волгоградского государственного университета. Серия 4, История. Регионоведение. Международные отношения. - 2021. T. 26, № 1. - C. 238-252. - DOI: https://doi.org/10.15688/jvolsu4.2021.1.21

Введение. Авторами статьи обосновывается идея познавательного потенциала, который содержит ретроспективная информация о некогда новых методах создания особого типа социалистических городов и экспериментальных подходах к архитектурному проектированию в стиле конструктивизма. Передовые практики применялись в гражданском (в том числе жилищном) строительстве «умного» и успешного социалистического города, носившего имя вождя, в частности, в создании типовых домов в рабочих поселках северной промзоны и «штучном» проектировании жилья для квалифицированных специалистов и административных зданий в Центральном, Краснооктябрьском, Ворошиловском районах города.
Важным аспектом в градостроительстве являлось отношение к созданию архитектурного ансамбля на главной площади города, который не был представлен в едином стиле, но отличался новизной и оригинальностью решений проектировщиков, включая сохранение части зданий дореволюционной поры с достройкой их верхними этажами. Данные вопросы имеют непосредственное отношение к востребованной ныне тематике исследований по локальной истории, социальной истории и актуальной проблеме информационнокультурного развития общества, так как предоставленный историко-аналитический материал необходим для 3D-реконструкции историко-архитектурных объектов довоенного и военного Сталинграда. 
Методы и материалы. Работа основывается на принципах историзма, научной объективности и системности. Для исследования истории архитектурного наследия Волгограда привлечены как общенаучные, так и специальные методы. Метод системного анализа применялся для возможности рассмотрения общего, единого культурного пространства мирного Сталинграда, формировавшегося в рамках нового направления в архитектуре - конструктивизма. Метод исторической и логической реконструкции позволил воссоздать облик архитектурного комплекса на площади Павших Борцов и прилегавших к ней улиц.

В работе используются информационносправочные материалы досоветского и советского периода, местные газеты, содержащие ценную информацию по истории строительства и работы Сталинградского универмага; архивные материалы фонда государственного архива Волгоградской области Ф. № Р-278 («Управление Сталинградского губернского инженера при Сталинградском губернском исполнительном комитете Совета рабочих, крестьянских и красноармейских депутатов (губинж), г. Сталинград»). Для визуального воссоздания общей картины площади Павших Борцов предвоенного и военного периодов авторы использовали фотоматериалы из фондов личного происхождения ГАВО - Ф. № Р-790 («Конов Лев Иванович - фотокорреспондент»). Основой для работы послужили научные труды отечественных авторов, посвященные градостроительству Сталинграда и особенностям архитектурных объектов главной площади города. Это монографии и статьи профессора П.П. Олейникова - исследователя проблемы исчезающей архитектуры Царицына и Сталинграда [14; 15], Н.П. Назаровой [13] и других авторов.

Анализ. Центральная площадь во все времена истории города являлась символическим, знаковым местом для горожан. В наши дни на городской площади проводятся социальные, общественно-политические, торжественные, а иногда - торговые мероприятия и парады. Главная площадь Волгограда относится к разновидности мемориальных площадей с установленным памятным обелиском на братской могиле погибших бойцов Красной армии в период Гражданской войны.
Площадь обрела новый современный облик после восстановительных работ в городе, продолжавшихся с 1943 г., когда начали восстанавливать корпуса заводов северной части Сталинграда, вплоть до 1953 г., когда завершилось восстановление и строительство новых объектов жилищного фонда. Здания и сооружения довоенного периода жизни города, в том числе площади Павших Борцов, были навсегда утрачены в период бомбардировки 23 августа 1942 гг., артобстрелов осажденного города и во время уличных боев. В мае 1943 г., согласно заключению Комиссии, рассматривающей вопросы восстановления Сталинграда, было решено провести перепланировку центра города, на отдельной его части приблизительно в 4 га [6, л. 66-67]. Это территория - от набережной Волги до железнодорожного вокзала. При этом перепланировка затронула большую, чем планировалось, часть центра города. По новому Генплану, в Сталинграде стали возводить монументальные здания, которые отражали мемориально-триумфальную тему в архитектуре города-героя.

Сегодня, благодаря новому потенциалу IT-технологий и методики виртуальной 3D-реконструкции исторических объектов, у волгоградских исследователей появилась возможность виртуально восстановить архитектурный ансамбль главной площади города, а также некоторых примеров 3D-сцен микрорайонов довоенного Сталинграда и знаковых историко-культурных объектов Царицына с целью детального изучения, создания виртуальных экскурсий и размещения в сети Интернет для общего доступа.

Перед началом рассмотрения исторических объектов, находившихся по периметру главной площади довоенного города, следует обратиться к истории создания всего архитектурного ансамбля площади. В целом ее облик сформировался на основе бывшей Александровской площади Царицына. Свое название площадь получила от строившегося с 1901 вплоть до 1918 г. на данной территории одноименного собора в честь Святого князя Александра Невского, служившего прихожанам до 1932 года.

За 17 лет строительства храма территория вокруг преобразилась за счет двух скве- 
ров, разбитых около него: в сторону железнодорожного вокзала уходил Гоголевский сквер с памятником писателю, а в южной стороне, ближе к Дому науки и искусств находился Городской сквер. В свое время площадь называлась Городской, а еще ранее - Базарной, так как рядом с ней находился основной базар центральной части Царицына, второй же по величине действовал в Зацарицынской части города. В царицынских рекламных объявлениях, а также в справочной литературе, причем выпуска одного года, часто указывались разные адреса проживания горожан и нахождения торговых домов на этой центральной территории. Например, в Справочнике за 1911 г. для «Второго общества взаимного кредита» (дом Н.И. Лапшина) и магазина И.С. Сивякова указывалось расположение - Александровская площадь; дом исправника В.А. Брещинского находился уже на Городской площади, еще более доходчиво был указан адрес Александровской мужской гимназии - «против городского сквера» [2, с. 86, 33, 113, 75].

Доминантой в архитектурном ансамбле площади Царицына, конечно, являлся Александро-Невский собор, занимавший $1 / 17$ еe пространства. Размеры храма были впечатляющими для города, застроенного двух-, трехэтажными зданиями. В частности, высота собора соответствовала 57,5 м, что сравнимо с высотой 18-этажного здания, длина -51 м, ширина - 47,5 м [8, с. 184]. Собор, построенный на народные средства - дары и пожертвования православных - был единственным в городе, созданном в русско-византийском стиле, но являлся основной достопримечательностью уездного центра. Возведен он из красного кирпича, фасад украшала полосатая и узорчатая кладка, причем кладка стен выстраивалась в четыре кирпича, а стены фундамента из тесаного камня достигали двух метров. При возведении собора характерна была основательность в расчетах и прочность в технологиях, с которыми его строили на века. Данное обстоятельство не помешало уничтожить храм в марте 1932 г. в угоду атеистических принципов жизни социалистического государства. Общественные богослужения в храме, который не отапливался с 1921 г., проводились до 1927 г., затем, до разрушения, здание приспособили под гараж.
Название «Павших борцов революции» площадь получила 8 февраля 1920 г., когда было решено переименовать ее после захоронения в братской могиле погибших бойцов Красной армии в дни обороны Царицына. В их честь через три года здесь был установлен деревянный памятный обелиск, который в 1925 г. был заменен каменным, высотой с двухэтажный дом [24]. С этого же года город стал носить имя Сталина.

Обелиск в то время находился напротив трехэтажной гостиницы «Столичные номера», ранее принадлежавшей маслозаводчикам, коммерсантам и благотворителям Ворониным.

Следует обозначить те изменения, которые касались всего градостроительства и благоустройства довоенного Сталинграда, а не только его главной площади. Интенсивно градостроение началось в конце 1920-х гг., в связи с поставленными задачами концепции по индустриализации страны и градостроительной политики. Сталинград входил в число 12 городов по созданию, а точнее - по реконструкции уже существующего в новый «социалистический город»- крупный индустриальный и культурный Нижневолжский центр, с тем, чтобы соответствовать новому социалистическому обществу [11, с. 244]. В связи с этим Сталинград 1928-1931 гг. стал грандиозной стройкой промышленных предприятий, прежде всего, первенца пятилетки - тракторного завода и его рабочих поселков. Среди других важных промышленных объектов отметим строительство в южных районах СталГРЭС и Красноармейской судоверфи. В это же время проводилась реконструкция крупных лесозаводов, техническая модернизация машиностроительного завода «Баррикады» и металлургического завода «Красный Октябрь», так как Сталинград оставался центром металлургии в Нижнем Поволжье и 9 \% всей выпускаемой стали в регионе производилось здесь [11, с. 242].

В целом для периода довоенного Сталинграда характерны крупные масштабы градостроительства как общественных, производственных, так и жилых объектов. Жилые комплексы строились в рабочих поселках Краснооктябрьского района и завода «Баррикады», Кировского района для трудящихся химического комби- 
ната, тоже являвшегося первенцем пятилетки. Например, согласно Генплану, по проекту архитекторов братьев А.А. и Л.А. Весненых вся протяженность территории города вдоль Волги была разделена на пять районов, как бы образующих отдельные города, каждый из которых состоял из 4-5 жилых комбинатов или домов-коммун. В коммунах, рассчитанных на 1,5-3,5 тыс. населения, были предусмотрены максимальные удобства для проживания советских людей с развитой системой бытового обслуживания. Согласно Генплану, в Сталинграде обеспечивалась хорошая связь «между жилищем и местами приложения труда (около 10-15 минут)» [3].

Разумеется, градостроительная концепция «социалистического расселения» утверждала главенство организуемой производственной деятельности, а «жизнь» и социум рассматривались как обслуживающие, обеспечивающие производство [12, с. 118].

Тем не менее автор концепции социалистического города, сотрудник Генплана СССР Л.М. Сабсович уделял большое значение построению социалистического общества в новых и «социалистически реконструируемых городах», как например, Сталинград. Экономист отмечал следующее: «Мы создадим условия для невиданного подъема коллективной самодеятельности массы во всех областях производственной и общественной работы, для выработки из каждого трудящегося нового человека, члена, творца нового социалистического, общества» [19, с. 122]. Необходимые условия создавались посредством специфики гражданского строительства, предусматривающего максимум необходимых удобств для самих строителей социалистического города. Именно с 1930-х гг. стала применяться поквартальная планировка и застройка жилых домов, предусматривающая все необходимые условия для проживания горожан как в рабочих поселках северной и южной промзон, так и в центральной части города. В частности, рядом с жилыми кварталами работников промышленных предприятий, а также ведомственными жилыми комплексами для ИТР в обязательном порядке располагались объекты коммунально-бытового хозяйства, медицинских служб, школ, садовяслей и зеленых зон для отдыха горожан. До- кументальный анализ источников свидетельствует о том, что важным являлся санитарно-гигиенический аспект, предписывающий в обязательном порядке иметь рядом с кварталами жилой застройки общественную прачечную, баню, а также «все дворы снабдить мусорными ящиками и провести древонасаждение» [17, л. 117-119]. Уделялось серьезное внимание работе прачечных и бань для населения. Так, в Сталинграде в 1932 г. действовало 26 бань, что на 10 единиц больше, чем в Саратове, но недостаточно было прачечных [23, с. 363-366].

В проектах жилых домов для рабочих промышленных объектов учитывались, к примеру, такие нюансы, как направление улиц, «дабы по возможности избежать их направления с запада на восток в целях правильного освещения жилищ», а значит, и экономии электричества [7, л. 4-5].

В обязательном порядке поблизости от жилой зоны располагались столовая и кулинария. Строительство «квартир с кухнями и всеми прочими удобствами, для ведения домашнего хозяйства» продолжалось как и прежде, так как предполагалось, что в социалистическом обществе семьи «быть может, не все сразу откажутся от самостоятельной варки пищи, то на ряду с общественной столовой в каждой квартире устроена небольшая газовая кухня» [19, с. 109]. Однако, согласно мнению идеолога концепции социалистического города, кухни в новой жизни являлись буржуазным пережитком и должны были уйти в прошлое, чтобы не отвлекать женщин от занятий общественно-производительным трудом [19, с. 102]. В связи с этим горожанам необходимы столовые и кулинарии.

В 1928 г. город стал центром округа в составе Нижневолжской области, а в 1932 г., в соответствии с постановлением ВЦИК центром Нижневолжского края [4, с. $447 ; 18$, л. 258]. Данный период жизни сталинградцев был связан с ответственным этапом по переводу и размещению всех организаций и структур административного аппарата из Саратова в Сталинград, которых было около 200 [14, с. 63,65$]$. Эти обстоятельства сильно повлияли на всю жизнь города, так как изыскать площади для размещения и нормального функционирования двух сотен учреждений, а также 
возможности для организации приемлемого жилья переезжавшим в город сотрудникам со своими семьями было делом ответственным и хлопотным. В итоге в 1934 г. Нижневолжский край был разделен на Сталинградский с центром в г. Сталинграде и Саратовский край с центром в г. Саратове, что значительно облегчило задачи партийному, хозяйственному руководству города и строителям по размещению организаций и новых сталинградцев [20, с. 43].

Генеральный план градостроительства Сталинграда был разработан в 1930 г. институтом «Гипрогор». История этого института связана с советским градостроением - от первых городов-новостроек: Кузбасса, Магнитки, Урала - до современного комплексного проектирования крупнейших административных и научных центров [9]. В частности, в 1930 г. конкретизация градостроительного проекта получила поддержку по предложениям строительства братьев А.А. и Л.А. Весниных (представителей института), являвшихся лидерами направления «конструктивизм» в советской архитектуре, которое особенно было популярно в первой половине 1930-х гг. [3].

Несмотря на недостаточность жилого фонда и возникшие проблемы с размещением технических специалистов и рабочих, необходимо отметить имевшиеся особенности в проектировке новых домов и реконструкции старых. Для довоенного Сталинграда, особенно для центра, было свойственно «штучное», а не серийное строительство однотипных зданий, имевших функциональное значение и различную ведомственную принадлежность. С последним нередко было связано название жилых и административных зданий, например, - здание Военведа, здание Легпрома, Дом грузчиков (построен для докеров речного порта), Дом коммунальщиков, Дом книги, дома специалистов, Дом просвещенцев и далее.

Особое отношение проявлялось к обеспечению жильем инженерно-технических кадров, профессорско-преподавательского состава сталинградских механического, медицинского, педагогического вузов и представителей других интеллигентных профессий. В частности, в 1930-х гг. были построены три жилых дома для ИТР (центр города), дом медиков (центр), дом профессуры Механического института (Тракторозаводской р-н), жилой дом работников искусств (центр). Выстроены и другие жилые объекты для представителей различных ведомств - дома НКВД, дома для работников облпотребсоюза. Ставший легендарным в период битвы за город дом сержанта Павлова - это жилой дом облпотребсоюза, в котором до бомбовых ударов конца августа 1942 г. еще жили семьи работников органа потребительской кооперации. Часть имевшихся зданий для жилья квалифицированных специалистов были отстроены вновь после войны.

Квартальная застройка в довоенном городе решала еще одну задачу - убиралась мелкая сеть старых улиц. Например, в центре города, сформировалась планировка с новой улицей Новосоветской и продолжением Октябрьской улицей, соответственно убирались 12 «“мелких” улиц» [14, с. 90].

В 1930 г. ленинградскими архитекторами-художниками был разработан генплан новой центральной части социалистического города Сталинграда [14, с. 8]. Было представлено 4 варианта проекта, в том числе согласно одному из них предполагалось превратить площадь 9 января в центральную. Однако не свершилось, и статус площади Павших Борцов остался важнейшим и центральным в городской среде. Это обстоятельство повлияло на кардинальное изменение облика главной городской площади. Начало формирования нового архитектурного комплекса площади Павших Борцов исследователи относят к 1928 г., так как в этом году вместо снесенного здания пожарной охраны было начато строительство первого пятиэтажного жилого дома Горко (городского коммунального отдела) на углу улицы Пушкинской и площади Павших Борцов. Сдан в эксплуатацию новый объект в 1930 г., а годом позднее к нему пристроили еще одно здание. Впоследствии Горко стал называться вторым домом Советов, но в довоенное и военное время больше был известен как Дом летчиков из-за пристройки к нему в 1931 г. училища летчиков [14, с. 150]. Именно это название объекта обозначено в некоторых военных картах. Дом летчиков находился на месте современного медуниверситета.

Обозначим, что с сооружением Дома летчиков и началось применение нового для 
Сталинграда архитектурного стиля - конструктивизма. Для данного архитектурного течения, особо оказавшегося по нраву советским архитекторам братьям А.А. и Л.А. Весниным, В.М. Гинзбургу, К.С. Мельникову, характерны «строгость, геометризм, лаконичность форм и функциональность зданий», а также контрастность сочетания больших площадей остекления зданий с фоном глухих поверхностей стен [1].

Ранее была отмечена проблема, возникшая в связи с необходимостью размещения двух сотен организаций и поселения семей сотрудников этих учреждений. Ситуация требовала значительного расширения строительных площадей и новаторских решений архитекторов и проектировщиков, которые не заставили себя ждать. Например, в центральной части города проектировщики предложили надстроить верхними этажами двух-трехэтажные здания царицынской постройки, что значительно увеличило полезные площади и «осовременило» городскую среду.

Проектированием городов в крае занимался институт «Крайпрогор», главным архитектором которого в начале 1930 -х гг. был архитектор Ф. Дюженко. Оригинальным решением архитектора стало проведение реконструкции бывшей гостиницы «Столичные номера», которая к тому времени называлась «Сталинградская». По проекту трехэтажное здание гостиницы было надстроено четвертым этажом [15]. Со временем в нем расположились универмаг и кинотеатр «Комсомолец», ставший популярным в довоенном Сталинграде.

Охват и широта застройки Площади изменили и ее планировку, особенно после уничтожения Александро-Невского собора, находившегося в ее центральной части. Новые формы планировки появились у зеленого сквеpa, так как его территория значительно расширилась. Памятник-обелиск и братскую могилу, оказавшиеся в результате перепланировки ближе к гостинице, то есть на оси бывшей улицы Московской, перенесли на новое место, где они сейчас и находятся. Перенос обелиска являлся тайной операцией, происходившей ночью [15].

Рядом с Драмтеатром им. Горького (бывший Дом Науки и Искусств), в северо-западной части Площади, в начале 1930-х гг. было построено четырехэтажное здание общежития крайисполкома. Сегодня это месторасположение соответствует трибунам площади.

По соседству с общежитием находилось одно из самых эффектных и красивых зданий Царицына, где ранее размещалось торговое товарищество Артемия Яблокова, которое впоследствии было отдано под Дом Красной армии. Здание стояло на углу улицы Гоголя и Площади и отличалось оригинальными архитектурными деталями крыши со своеобразными башенками, шпилями, свойственными постройке города конца XIX столетия. В сети Интернет можно найти цветную открытку Царицына времен Первой мировой войны с изображением этого эффектного здания. По проекту архитекторов П. Калиниченко и И. Иващенко этот дом был надстроен двумя этажами. Следует отметить, что проектировщикам удалось сохранить самобытность этого царицынского дома. Относительно полезных площадей: «...на четвертом этаже здания были размещены ясли на 100 детей и комнаты для кружковой работы семей начсостава. На третьем этаже - библиотека, читальня, лекционный зал на 250 человек и кабинеты для индивидуальных занятий. На втором этаже оборудуется зрительный зал на 350 человек, танцевальный зал на 100 человек, фойе, кафе и бильярдная» [15]. В этом же здании работал детский клуб юнармейцев.

Перспектива улицы Гоголя уходила на северо-запад и замыкалась на привокзальной площади с вокзалом Сталинград I. Здание не было подвергнуто радикальной реконструкции: сохранилось в историческом виде со времен его постройки для Грязе-Царицынской железной дороги левое крыло вокзала, но был достроен второй этаж вокзала и большое правое крыло в 1930-х годах.

Именно Центральный вокзал Сталинград I и прилегающие к нему дома и сооружения стали эпицентром оборонительных боев в центральной части города, с середины до конца сентября 1942 г. (14.09-26.09.1942 г.). Вокзал, серьезно поврежденный авиацией и артиллерией, все еще оставался важным стратегическим объектом осажденного города, который некоторое время был способен функционировать. В боях за вокзал и прилегающие к нему территории и здания особо отличились бойцы 
1-го батальона 42-го Гвардейского стрелкового полка 13-й Гвардейской стрелковой дивизии, комбатом которого вначале был старший лейтенант 3.П. Червяков. После его тяжелого ранения командование батальоном взял на себя старший лейтенант Ф.Г. Федосеев $[10$, с. 110$]$.

Напротив привокзальной площади находились музей Обороны Красного Царицына и гвоздильный завод «Красная застава», который построен еще царицынскими коммерсантами братьями Серебряковыми. Район обороны батальона после тяжелых боев протянулся от вокзала до здания универмага, включая гвоздильный завод и высотный Дом коммунальщиков. Эти объекты являлись узлами сопротивления в сентябре 1942 года. К истории появления красивой высотки - Дома коммунальщиков - вернемся позднее.

В довоенном Сталинграде на противоположной от Дома Красной армии территории, через дорогу улицы Гоголя, в 1935 г. была построена самая крупная гостиница в городе «Большая Сталинградская» (вторая гостиница, ныне на этом месте находится здание Главпочтамта). Ее фасад выходил к ГУМу, построенному в 1938 году. Гостиница была рассчитана на 230 номеров, рядом, по улице Гоголя, находилась гостиница «Люкс» царицынской постройки. Здание «Большой Сталинградской» несло еще и смысловую нагрузку в архитектурном оформлении Площади, отличаясь своими объемами и монументальностью строения. По соседству со строившимся зданием универмага одновременно возводилась гостиница «Интурист» (1-я гостиница), немногим уступая «Большой Сталинградской» по количеству номеров. Вплотную с ней построили здание Облместпрома (Легпрома), где впоследствии расположились и администрация, и жилые квартиры сотрудников [15].

Подобно бывшему дому А. Яблокова, двумя этажами был надстроен и бывший особняк мецената А.А. Репникова, находившийся ранее на центральной ул. Царицына Александровской, напротив Александровской площади. В Сталинграде в этом уже четырехэтажном здании на улице Октябрьской разместили Главпочтамт, учреждения Наркомтяжпрома и Пищепрома. На углу улиц Московской и Октябрьской, на одной оси с Глав- почтамтом был возведен новый Дом книги. Судя по фотоматериалам, за этими двумя зданиями начинался выход к верхнему ярусу центральной Набережной.

Фотографические источники и документы кинохроники позволяют понять, что вновь построенные здания, создавшие архитектурный ансамбль главной городской площади, также были выполнены в стиле конструктивизма и отличались строгостью оформления фасадов, редкими украшательскими деталями, большим количеством окон, что производит впечатление их монументальности, но в то же время просматривается своеобразная «пролетарская» эстетика, которая в целом характерна для индустриальной культуры центра Нижнего Поволжья. Тем не менее в целом архитектурный ансамбль создает впечатление благоустроенности центральной части довоенного Сталинграда (см. рис. 1).

Ранее было отмечено, что многие здания в строившемся социалистическом городе возводились непо типовым, а по индивидуальным проектам, с использованием передовых технологий того времени. Более того, в Краснооктябрьском, Центральном и Ворошиловском районах города была построена группа домов, композиционно выделявшихся на фоне других, с округленным фасадом или углом, с повышенной угловой частью, иногда завершавшейся ротондой. Как правило, скругленный объем был характерен для угловых зданий. К примеру, это ГУМ, Дом грузчиков, Дом консервщиков (построен для работников консервного завода), Облисполком, Дом просвещенцев, Дом гидролизного завода и другие.

Особенно оригинальным, красивым и самым высоким в городе был семиэтажный Дом коммунальщиков, также выполненный в стиле «провинциального» конструктивизма (1937 г.). Согласно мнению волгоградского архитектора П.П. Олейникова, высказанному в интервью, этот Дом считался не только одним из красивейших в довоенном Сталинграде, но и был самой крупной постройкой на Нижней Волге. «На его полукруглом парадном фасаде красовались колонны, изящные балкончики. На крыше находилась площадка для отдыха» [5]. Здание было расположено по соседству с гвоздильным заводом, рядом с музеем Обороны Красного Царицына, то есть 
территориально - недалеко от железнодорожного вокзала и площади Павших Борцов.

Как отмечено ранее, в период уличных боев в городе, с середины сентября 1942 г. это здание находилось в эпицентре сражения за железнодорожный вокзал, но и впоследствии оставшиеся от здания руины сыграли свою положительную роль как прикрытие в наступательный период при окружении немецких войск в январе 1943 года.

Стоит отметить, что и взорванный на Площади «собор» смог послужить людям в военном Сталинграде, так как использовались остатки его кирпичей, щебень и каменная крошка при строительстве уличных баррикад возле зданий на Площади. В частности, баррикады из камней и щебня загораживали подходы к Универмагу, гостинице «Сталинградской», улицам Островского, Гоголя. Осколки кирпичей, камня, бетона в значительном количестве остались после взрыва собора и служили в качестве подушки для дороги на окружавших Площадь улицах и скверах [8, с. 181].

В дальнейшем вся нечетная сторона домов улицы Гоголя, включая Дом Красной армии, сильно пострадала от августовских бомбежек 1942 г. и артобстрелов во время боев за город.

В городе довоенной поры перестроенная Площадь обрела архитектурно оформленный общий вид уже к лету 1936 г., хотя строительство некоторых объектов продолжалось. В Городском сквере подросли молодые деревья и кустарники, появились новые дорожки, ограды и фонари, скамейки и парковые украшения; заработали два фонтана [21]. Формирование ансамбля Площади продолжилось: в западной части Площади, в начале бывшей ул. Первомайской, было возведено четырехэтажное здание для Крайисполкома (в дальнейшем облисполкома). Объект введен в эксплуатацию 1937 г., композиционно также был решен в стиле конструктивизма, с округленным углом, увенчанным ротондой [15].

Завершен архитектурный ансамбль площади Павших Борцов был в 1938 г. с возведением нового здания универмага. Этот объект, в подвале которого был пленен командующий 6-й полевой армии генерал-фель- дмаршал Ф. Паулюс и его штаб, и сегодня остается одним из символов города-героя. В наши дни старый универмаг скрыт за стеклянным фасадом волгоградского центрального универмага.

Здание универмага, выполненное в стиле конструктивизма с элементами историзма, с округленным углом, увенчанным ротондой, являлось по меркам социалистического города «долгостроем». Его постройка продолжалась более двух лет из-за недостатка квалифицированных рабочих-строителей, стройматериалов и техники. Не хватало также оборудования для магазина, но проблема была решена собственными силами, что было особо отмечено в местной газете: «...в подвалах универмага организовали столярные мастерские, где мастера профессионально изготовили необходимое оборудование, мебель и прилавки» [21].

Долгожданное открытие Показательного Универмага состоялось в июне 1938 г. Здание с полукруглым фасадом выделялось на фоне других, но эффектно смотрелось рядом с Домом Красной армии, который находился напротив, через ул. Ломоносовскую, и также имел закругленный фасад. Малое крыло универмага примыкало к гостинице «Интурист» и выходило на площадь Павших Борцов [22].

Работа нового Сталинградского универмага по своим основным показателям приравнивалась к 6 лучшим в СССР, которых на тот момент всего было 21. В универмаге насчитывалось около 500 сотрудников, а некоторые товары, поступавшие в продажу, например, модельную обувь, можно было заказать лишь в четырех магазинах страны [21].

С возведением здания универмага архитектурный ансамбль Площади был завершен (см. рис. 2). Как отмечает архитектор П.П. Олейников, с 1928 по 1938 гг. на площади Павших Борцов было построено 8 новых зданий и реконструировано 4 здания царицынской архитектуры [15].

После августовского массированного удара немецкой авиации по Сталинграду многие здания, в том числе на площади Павших Борцов, были разрушены, выгорели. У автора Е. Кобякова имеется упоминание о пребывании в начале сентября в осажденном городе корреспондентов и редактора газеты «Крас- 
ная Звезда» Д. Ортенберга, писателей К. Симонова, В. Коротеева и фотографа В. Темина. Газетчики, пройдя по мертвым улицам к привокзальной площади, сделали несколько снимков, в том числе фонтана на привокзальной площади - «гипсовые дети посреди изуродованного города производили жуткое впечатление» $[10$, с. 96$]$.

В середине сентября, когда вокзал у немцев был отбит на несколько дней, немецкая авиация также методично бомбила и здание вокзала, и близлежащие кварталы. Сильно пострадали Дом коммунальщиков, Облисполком и его общежитие, Легпром, Дом книги, школа летчиков - все объекты находились рядом с площадью Павших Борцов.

26 сентября 1942 г. был закончен первый штурм Сталинграда. Частями 6-й армии генерала Паулюса и 4-й танковой армии генерал-полковника Гота были захвачены южный (Ворошиловский р-н, пос. Купоросный) и Центральный районы города $[10$, с. 158]. На административных партийных и советских зданиях Площади были вывешены флаги противника. Бои за город продолжались, но переместились в северную промзону и рабочие поселки заводов.

В послевоенное время, 16 февраля 1943 г., когда было снято осадное положение в городе, необходимо было приводить в норму санитарное состояние - захоронение трупов, разгребание завалов, разбор руин и постоянное разминирование территории. Большую роль на данном этапе сыграли общественные организации и добровольцы. Так, к июню 1943 г. в основном силами горожан было освобождено от мусора и нечистот 800 тыс. м² улиц, площадей, садов, разобрано 2100 м $^{3}$ баррикад, засыпано 600 шт. помойных ям, свалок, старых уборных, построены 45 общественных уборных и 31 мусорный ящик [16, с. 68]. Работы по захоронению трупов и разбору завалов продолжались долго. Центральная часть города - административные и жилые здания строились после восстановления промышленных объектов.

Результаты. Здания и сооружения довоенного Сталинграда, представлявшие облик городской среды социалистического города, включая площадь Павших Борцов, были навсегда утрачены для потомков. В централь- ной части города фактически остались одни руины, которые были снесены - это разрушенные коробки здания облисполкома, его общежития, Дома Красной армии и многих других. Следует отметить, что восстановлено было здание универмага, которое в дни битвы за город имело выгодное местоположение. После жестоких боев, в октябре 1942 г. в его больших подвальных помещениях разместился штаб 71-й дивизии вермахта, расквартировав свои полки в центре города. Против них держала линию фронта 13-я гвардейская дивизия, занимавшая позиции ближе к Волге и домам специалистов [10, с. 128]. В январе 1943 г. подвалы универмага занял штаб 6-й армии и ее командующий Ф. Паулюс, где и был пленен 31 января бойцами 38-й мотострелковой бригады 64-й армии под командованием И.В. Бурмакова.

Весь довоенный ансамбль Площади необходимо было создавать заново. По этой причине в восстановительный период жизни города руины зданий были разобраны, за основу восстановления, вернее строительства нового города был взят Генеральный план Сталинграда академика архитектуры К. Алабяна. Центральная часть города, включая площадь Павших Борцов, ул. Мира, набережную Волги, отстраивалась по проекту В.Н. Симбирцева - главного архитектора послевоенного города $[13$, с. 24$]$.

Архитектурный облик послевоенной застройки Площади значительно изменился, конструктивизм ушел в прошлое, в облике города-героя появилось новое мемориально-триумфальное архитектурное направление. Как отмечено выше, сохранено было здание универмага и в меньшей степени изменению подвергся Дом коммуны. На фундаментах этого дома впоследствии была построена пятиэтажная гостиница «Волгоград», реконструировано и здание бывшего драмтеатра.

Тем не менее следует отметить оригинальность новых практик, применявшихся в проектировании и строительстве города 1930-х гг., в частности, жилых домов и гражданских объектов. Если не акцентировать внимание на идеологической составляющей концепции «социалистических городов», то существенным и актуальным даже в наши дни является подход архитекторов и 


\section{ИСТОРИЧЕСКАЯ ПАМЯТЬ О ВОЕННЫХ СОБЫТИЯХ}

проектировщиков к процессу формообразования Сталинграда, который рассматривался в трех аспектах: функциональном, композиционном и образном.

Утраченные историко-культурные объекты довоенного Сталинграда, в частности, ансамбль главной городской Площади, вокзал, набережная, будут воссозданы волгоградскими исследователями вновь, но в виртуальном виде, на основе методологии 3D-реконструкции сооружений. Данная работа необходима для современников и последующих поколений, чтобы знать о различных этапах жизни Волгограда с характерными для них обликом и чертами, всегда отражающими особенности окружающей среды города.

\section{ПРИМЕЧАНИЕ}

1 Работа выполнена при финансовой поддержке Минобрнауки России в рамках проекта № 06332020-0004 «Развитие методики виртуальной 3D реконструкции исторических объектов».

The study was financially supported by the Ministry of Science and Higher Education of the Russian Federation as research project no. 0633-2020-0004 "Development of methods of virtual 3D reconstruction of historical objects". 


\section{ПРИЛОЖЕНИЕ}

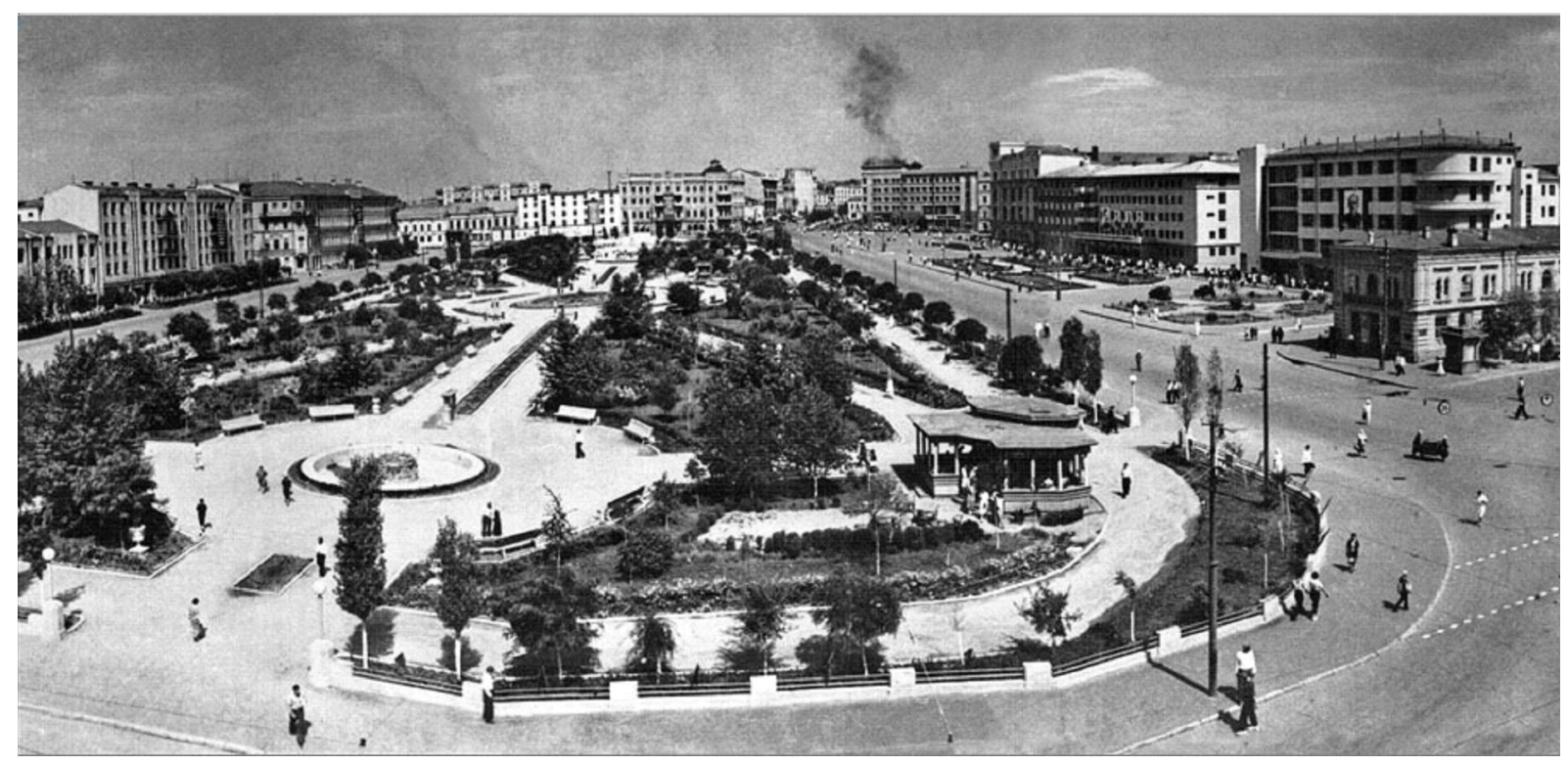

Рис. 1. Панорама площади Павших Борцов со стороны улицы Октябрьской (ныне проспект им. Ленина, обелиск воинам установлен на противоположной стороне площади), 1939-1940 гг.

Fig. 1. Panorama of the Square of Fallen Fighters from the side of Oktyabrskaya St (now Prosp. Lenina, the obelisk to soldiers is installed on the opposite side of the square), 1939-1940

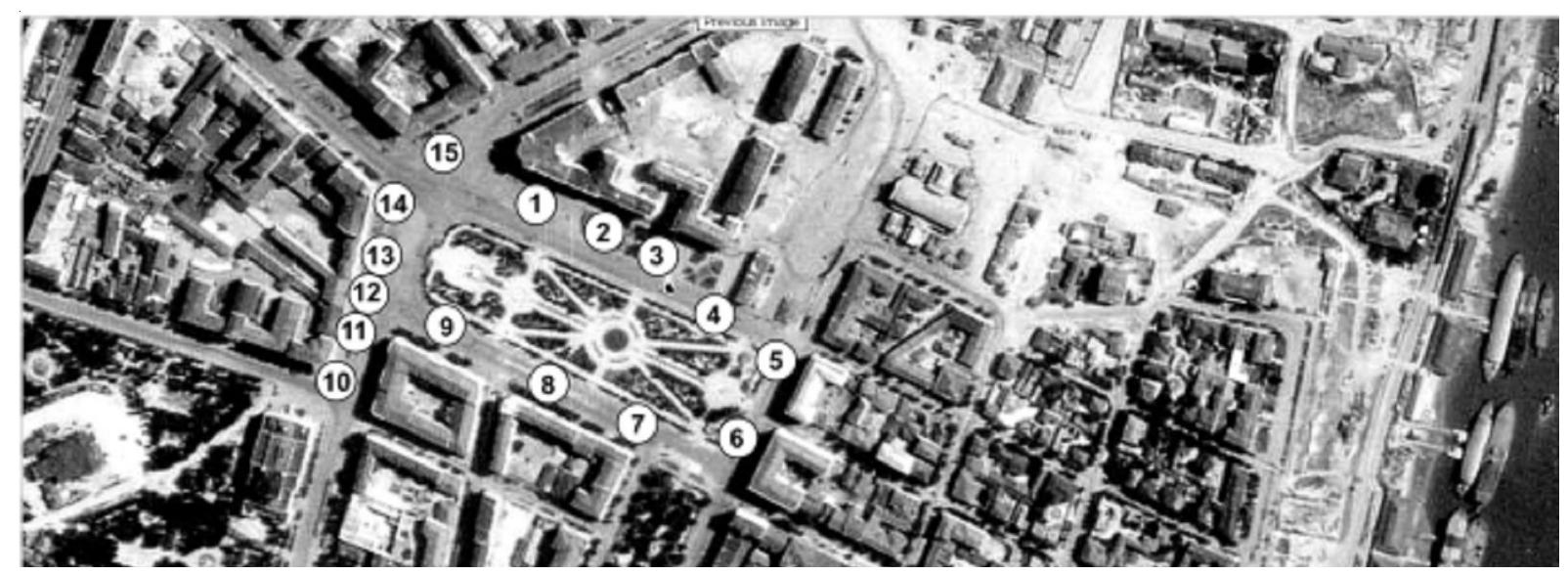

Рис. 2. План центральной части города. Ансамбль площади Павших Борцов в 1942 г.:

1 - ЦУМ; 2 - гостиница Интурист; 3 - здание Легпрома; 4 - швейная мастерская;

5 - здание Уполнаркомпищепрома; 6 - Главпочтамт; 7 - школа летчиков; 8 - Дом летчиков; 9 - Дом Советов; 10 - здание облисполкома; 11 - жилой дом (бывшая аптека Забелина); 12 - здание Военведа;

13 - общежитие облисполкома; 14 - Дом Красной армии; 15 - гостиница «Большая Сталинградская»

Fig. 2. Plan of the central part of the city. The ensemble of the Square of Fallen Fighters in 1942:

1 - Central Department Store; 2 - Intourist hotel; 3 -building of light industry; 4 - sewing workshop;

5 - Upolnarkompishcheprom building; 6 - Central post office; 7 - pilot school; 8 - Pilot House; 9 - House of Soviets; 10 - building of the Regional Executive Committee; 11 - dwelling house (former Zabelin pharmacy); 12 - building of Voenved; 13 - dormitory of the Regional Executive Committee; 14 - House of the Red army; 15 - "Bolshaya Stalingradskaya" hotel 


\section{СПИСОК ЛИТЕРАТУРЫ}

1. Архитектурный стиль: конструктивизм. Электрон. текстовые дан. - Режим доступа: https:// www.regent-decor.ru/lib/articles/architecture/ konstruktivizm.html (дата обращения: 10.09.2020).Загл. с экрана.

2. Весь Царицын. Справочник по гор. Царицыну и Царицынскому уезду за 1911 г. - Царицын : Царицынская мысль, 1911. - 113 с.

3. Генеральный план Сталинграда. А. и Л. Веснины. 1930 г. - Электрон. текстовые дан. - Режим доступа: http://arx.novosibdom.ru/node/2384 (дата обращения: 10.09.2020). - Загл. с экрана.

4. Государственный архив Волгоградской области : Путеводитель / Е. В. Булюлина [и др.]. - Волгоград : Изд-во ВолГУ, 2002. - 572 с.

5. Гречухина, Ю. В Волгограде открыта выставка «Здания - крепости Сталинграда» / Ю. Гречухина // Волгоградская правда. - 2019. - 27 авг. Электрон. текстовые дан. - Режим доступа: https:// vpravda.ru/kultura/v-volgograde-otkryta-vystavkazdaniya-kreposti-stalingrada-75421 (дата обращения: 15.09.2020). - Загл. с экрана.

6. Докладная записка секретаря Сталинградского обкома ВКП(б) А. С. Чуянова и председателя Сталинградского облисполкома И. Ф. Зименкова Г. М. Маленкову и Н. А. Вознесенскому с предложениями по планировке центральной части Сталинграда от 25 мая 1943 г. // Российский государственный архив социально-политической истории (РГАСПИ). - Ф. 17. - ОП. 121. - Д. 195. - Л. 66-67.

7. Заключение по Акту приемки поселка им. А. И. Рыкова от 5 января 1926 г. // Государственный архив Волгоградской области (далее - ГАВО). Ф. 278. - Оп. 1. - Д. 35. - Л. 4-5.

8. Иванов, С. М. Православие на волгоградской земле: храмы Царицына - Сталинграда - Волгограда / С. М. Иванов, В. И. Супрун. - Волгоград : Изд-во ВГИПК РО, 2003. - 240 с.

9. Из истории института «Гипрогор». - Электрон. текстовые дан. - Режим доступа: http://www. giprogor.ru/about/history (дата обращения: 10.09.2020). - Загл. с экрана.

10. Кобяков, Е. Неизвестный Сталинград / Е. Кобяков. - М. : Яуза-каталог, 2020. - 320 с.

11. Липатов, А. В. Социалистическое преобразование города в 1930-е гг: Сталинград как социальноэкономический центр Нижнего Поволжья / А. В. Липатов, Ф. А. Такташева // Документ. Архив. История. Современность : сб. науч. тр. - Екатеринбург : Изд-во Урал. ун-та, 2018. - Вып. 18. - С. 241-246.

12. Меерович, М. Г. Градостроительная доктрина России. Исторические предпосылки / М. Г. Меерович // Вестник Иркутского государственного технического университета. - 2003. - № 1 (13). - С. 116-123.
13. Назарова, М. П. Исчезнувший и возрожденный: архитектура Сталинграда до и после Сталинградской битвы / М. П. Назарова, П. П. Олейников // Социология города. - 2013. - № 1. - С. 20-26.

14. Олейников, П. П. Архитектурное наследие Сталинграда / П. П. Олейников. - Волгоград : Издатель, 2012. -560 с.

15. Олейников, П. П. Формирование градостроительного ансамбля площади Павших Борцов в довоенном Сталинграде / П. П. Олейников [и др.] // Интернет-вестник ВолгГАСУ. Серия: Политематическая. - 2011. - Вып. 1 (15). - Электрон. текстовые дан. - Режим доступа: http://vestnik.vgasu.ru/ attachments/OleinikovAntyufeyev-2011_1(15).pdf (дата обращения: 10.09.2020). - Загл. с экрана.

16. Пищулина, С. Ю. Восстановление Сталинграда в 1943-1945 гг.: проблема формирования и распределения трудовых ресурсов / С. Ю. Пищулина, О. Ю. Редькина // Экономическая история. - 2017. № 38. - С. 64-77.

17. План поселков Большая и Малая Франция на заводе «Красный октябрь». 1926 г. // ГАВО. Ф. 278. - Оп. 1. - Д. 112. - Л. 117-119.

18. Протокол № 33Д. № АУ 715/14 от 10 января 1932 г. «О переводе центра Нижневолжского края из г. Саратова в г. Сталинград» // ГАВО. - Ф. Р-313. Оп. 1. - Д. 68. - Л. 258.

19. Сабсович, Л. М. Социалистические города. Госиздат РСФСР / Л. М. Сабсович. - М. : Московский рабочий, 1930. - 124 с.

20. Собрание узаконений РСФСР (СУ РСФСР).1934. - № 5. - Ст. 34. - С. 43.

21. Сталинградский Показательный Универмаг // Сталинградская битва. - Электрон. текстовые дан. - Режим доступа: https://stalingrad-battle. ru/projects/emploee-writes/2014/4021 (дата обращения: 12.09.2020). - Загл. с экрана.

22. Сталинградский универмаг // Сталинградская правда. - 1936. - 7 нояб. - С. 3.

23. Статистический справочник Нижней Волги (1929-1933). Сталинград, 1934 / Нижневолжский Крайплан - Крайунху. - Сталинград : Изд. журнала «Нижнее Поволжье», 1934. - 459 с.

24. Тогда и сейчас: эволюция площади Павших Борцов // Блокнот. - Электрон. текстовые дан. - Режим доступа: https://bloknot-volgograd.ru/news/ togda-i-seychas-evolyutsiya-ploshchadi-pavshikh-bo917904 (дата обращения: 10.09.2020). - Загл. с экрана.

\section{REFERENCES}

1. Arhitekturnyj stil': konstruktivizm [Architectural Style: Constructivism]. URL: https:// www.regent-decor.ru/lib/articles/architecture/ konstruktivizm.html (accessed 10 September 2020). 
2. Ves' Caricyn. Spravochnik po gor. Caricynu i Caricynskomu uezdu za 1911 g. [All Tsaritsyn. Reference Book on the City of Tsaritsyn and Tsaritsyn Uyezd for 1911]. Tsaritsyn, Tsaritsynskaya mysl Publ., $1911.113 \mathrm{p}$.

3. General'nyj plan Stalingrada. A. i L. Vesniny. $1930 \mathrm{~g}$. [General Plan of Stalingrad. A. and L. Vesnins. 1930]. URL: http://arx.novosibdom.ru/node/ 2384 (accessed 10 September 2020).

4. Bulyulina E.V., Garskov I.V., Kadashova V.M. et al. Gosudarstvennyj arhiv Volgogradskoj oblasti: Putevoditel' [State Archive of Volgograd Region: Guide]. Volgograd, Izd-vo VolGU, 2002. 572 p.

5. Grechuhina Ju. V Volgograde otkryta vystavka «Zdanija - kreposti Stalingrada» [The Exhibition "Buildings - Fortresses of Stalingrad" Is Open in Volgograd]. Volgogradskaja Pravda, 27 August 2019. URL: https://vpravda.ru/kultura/v-volgograde-otkrytavystavka-zdaniya-kreposti-stalingrada-75421/ (accessed 15 September 2020).

6. Dokladnaja zapiska sekretarja Stalingradskogo obkoma VKP(b) A.S. Chujanova i predsedatelja Stalingradskogo oblispolkoma I.F. Zimenkova G.M. Malenkovu i N.A. Voznesenskomu s predlozhenijami po planirovke central'noj chasti Stalingrada ot 25 maja 1943 g. [Report of the Secretary of the Stalingrad Regional Committee of the CPSU(b) A.S. Chuyanov and the Chairman of the Stalingrad Regional Executive Committee I.F. Zimenkov to G.M. Malenkov and N.A. Voznesensky with Proposals for Planning the Central Part of Stalingrad Dated May 25, 1943]. Rossijskij gosudarstvennyj arhiv social'nopoliticheskoj istorii (RGASPI) [Russian State Archive of Socio-Political History], f. 17, inv. 121, d. 195, 1. 66-67.

7. Zakljuchenie po Aktu priemki poselka im. A.I. Rykova ot 5 janvarja $1926 \mathrm{~g}$. [Conclusion on the Act of Acceptance of the Settlement Named After A.I. Rykov of January 5, 1926]. Gosudarstvennyy arhiv Volgogradskoy oblasti (GAVO) [State Archive of Volgograd Region], f. 278, inv. 1, d. 35, 1. 4-5.

8. Ivanov S.M., Suprun V.I. Pravoslavie na volgogradskoi zemle: khramy Tsaritsyna Stalingrada - Volgograda [Orthodoxy on Volgograd Land: Churches of Tsaritsyn - Stalingrad - Volgograd]. Volgograd, Izd-vo VGIPK RO, 2003. $240 \mathrm{p}$.

9. Iz istorii instituta "Giprogor» [From the History of "Giprogor" Institute]. URL: http://www.giprogor.ru/ about/history (accessed 10 September 2020).

10. Kobyakov E. Neizvestnyj Stalingrad [Unknown Stalingrad]. Moscow, Yauza-katalog Publ., 2020.320 p.

11. Lipatov A.V., Taktasheva F.A. Socialisticheskoe preobrazovanie goroda v 1930-e gg.: Stalingrad kak social'no-jekonomicheskij centr Nizhnego Povolzh'ja [Socialist Transformation of the City in the 1930s: Stalingrad as the Socio-Economic Center of the Lower
Volga Region]. Dokument. Arhiv. Istorija. Sovremennost': sb. nauch. tr. [Document. Archive. History. Modernity. Collection of Scientific Works]. Yekaterinburg, Izd-vo Uralskogo universiteta, 2018, iss. 18, pp. 241-246.

12. Meerovich M.G. Gradostroitel'naja doktrina Rossii. Istoricheskie predposylki [Urban Planning Doctrine of Russia. Historical Prerequisites]. Vestnik Irkutskogo gosudarstvennogo tehnicheskogo universiteta [Bulletin of Irkutsk State Technical University], 2003, no. 1 (13), pp. 116-123.

13. Nazarova M.P., Oleynikov P.P. Ischeznuvshij i vozrozhdennyj: arhitektura Stalingrada do i posle Stalingradskoj bitvy [Disappeared and Revived: The Architecture of Stalingrad Before and After the Battle of Stalingrad]. Sociologija goroda [Sociology of the City], 2013, no. 1, pp. 20-26.

14. Oleinikov P.P. Arkhitekturnoe nasledie Stalingrada [Architectural Heritage of Stalingrad]. Volgograd, Izdatel Publ., 2012. 560 p.

15. OleinikovP.P., Antyufeev A.V., Ptichnikova G.A., Sharyga N.P. Formirovanie gradostroitel'nogo ansamblja ploshhadi Pavshih Borcov v dovoennom Stalingrade [Formation of the Urban Planning Ensemble of the Square of the Fallen Fighters in PreWar Stalingrad]. Internet-vestnik VolgGASU. Seriya: Politematicheskaja [Internet Bulletin of VolgGASU. Series: Polythematic], 2011, iss. 1 (15). URL: http:// vestnik.vgasu.ru/attachments/OleinikovAntyufeyev2011_1(15).pdf(accessed 10 September 2020).

16. Pishchulina S.Yu., Redkina O.Yu. Vosstanovlenie Stalingrada v 1943-1945 gg.: problema formirovanija i raspredelenija trudovyh resursov [Restoration of Stalingrad in 1943-1945: The Problem of the Formation and Distribution of Labor Resources]. Jekonomicheskaja istorija [Economic History], 2017, no. 38, pp. 64-77.

17. Plan poselkov Bol'shaja i Malaja Francija na zavode «Krasnyj oktjabr'». $1926 \mathrm{~g}$. [The Plan of the Villages of Bolshaya and Malaya France at the Red October Plant]. GAVO [State Archive of Volgograd Region], f. 278, inv. 1, d. 112, 1. 117-119.

18. Protokol № 33D. № AU 715/14 ot 10 janvarja 1932 g. «O perevode centra Nizhnevolzhskogo kraja iz g. Saratova v g. Stalingrad» [Protocol No. 33D. No. AU 715/14 Dated January 10, 1932 "On the Transfer of the Center of the Lower Volga Region from Saratov to Stalingrad"]. GAVO [State Archive of Volgograd Region], f. R-313, inv. 1, d. 68, 1. 258.

19. Sabsovich L.M. Socialisticheskie goroda. Gosizdat RSFSR [Socialist Cities. State Publishing House of the RSFSR]. Moscow, Moskovskiy rabochiy Publ., 1930. $124 \mathrm{p}$.

20. Sobranie uzakonenij RSFSR (SU RSFSR) [Collection of Legislation of the RSFSR], 1934, no. 5, art. 34, p. 43. 
21. Stalingradskij Pokazatel'nyj Univermag [Stalingrad Demonstration Department Store]. Stalingradskaja bitva [Battle of Stalingrad]. URL: https://stalingrad-battle.ru/projects/emploee-writes/ 2014/4021/ (accessed 12 September 2020).

22. Stalingradskij univermag [Stalingrad Department Store]. Stalingradskaja Pravda, 1936, November 7, p. 3.

23. Statisticheskij spravochnik Nizhnej Volgi (1929-1933). Stalingrad, 1934 [Statistical Handbook of the Lower Volga (1929-1933). Stalingrad, 1934]. Stalingrad, Izd-vo zhurnala «Nizhnee Povolzhye», $1934.459 \mathrm{p}$.

24. Togda i sejchas: jevoljucija ploshhadi Pavshih Borcov [Then and Now: Evolution of the Square of Fallen Fighters]. Bloknot. URL: https:// bloknot-volgograd.ru/news/togda-i-seychasevolyutsiya-ploshchadi-pavshikh-bo-917904 (accessed 10 September 2020).

\section{Information About the Authors}

Irina N. Litvinova, Candidate of Sciences (History), Senior Researcher, Laboratory of Spatial Analysis of Data, Historical Reconstruction and Modeling, Volgograd State University, Prosp. Universitetsky, 100, 400062 Volgograd, Russian Federation, litvinova@volsu.ru, https://orcid.org/0000-0002-0611-336X

Oksana A. Karagodina, Candidate of Sciences (Philosophy), Researcher, Laboratory of Spatial Analysis of Data, Historical Reconstruction and Modeling, Volgograd State University, Prosp. Universitetsky, 100, 400062 Volgograd, Russian Federation, karagodina@volsu.ru, https://orcid.org/0000-0002-8337-4942

\section{Информация об авторах}

Ирина Николаевна Литвинова, кандидат исторических наук, старший научный сотрудник Лаборатории пространственного анализа данных, исторической реконструкции и моделирования, Волгоградский государственный университет, просп. Университетский, 100, 400062 г. Волгоград, Российская Федерация, litvinova@volsu.ru, https://orcid.org/0000-0002-0611-336X

Оксана Александровна Карагодина, кандидат философских наук, научный сотрудник Лаборатории пространственного анализа данных, исторической реконструкции и моделирования, Волгоградский государственный университет, просп. Университетский, 100, 400062 г. Волгоград, Российская Федерация, karagodina@volsu.ru, https://orcid.org/0000-0002-8337-4942 